\title{
Salinity effects on leaf ion composition and salt secretion rate in Avicennia germinans (L.) L.
}

\author{
Nathalie Suárez ${ }^{1,2 *}$ and Ernesto Medina ${ }^{1}$
}

${ }^{1}$ Laboratorio de Ecofisiología Vegetal, Instituto Venezolano de Investigaciones Científicas, Caracas 1020-A, Apartado 21.827, Venezuela. ${ }^{2}$ Present Address: Departamento de Biología de Organismos, Universidad Simón Bolívar, Apartado 89.000, Caracas 1080-A, Venezuela. ${ }^{*}$ Corresponding author: natsuare@usb.ve. Fax: +58 2129063046

Received: 13 May 2008; Returned for revision: 19 June 2008; Accepted: 25 June 2008

The effect of salinity on leaf water relations, and rate and ionic composition of leaf secretion was investigated in plants of Avicennia germinans growing under controlled salinity conditions. Increases in salinity from 0 to $940 \mathrm{~mol} \mathrm{NaCl} \mathrm{m}^{-3}$ reduced the predawn water potential from -0.56 to $-4.16 \mathrm{MPa}$ and the solute potential from -2.27 to $-4.48 \mathrm{MPa}$, whereas the pressure potential remained positive in all treatments. Compared to the control, at $940 \mathrm{~mol} \mathrm{NaCl} \mathrm{m} \mathrm{Na}^{-}$and $\mathrm{Cl}^{-}$ concentrations of leaf sap increased 19 and 7 times, respectively. With the addition of salt the main ions accumulated in leaves were $\mathrm{Na}^{+}$and $\mathrm{Cl}^{-}$whereas plants grown without salt accumulated $\mathrm{K}^{+}$in leaves at levels similar to those of $\mathrm{Na}^{+}$with salt treatments. Secretion rates of $\mathrm{Na}^{+}$and $\mathrm{Cl}^{-}$ions increased up to the highest salinity treatment, amounting to 59 and 46 times respectively, compared to control plants. The increase in secretion rate contributed to counteract the increase of salt concentration in the leaf. In the treatments receiving salts, the $\mathrm{Na}^{+} / \mathrm{K}^{+}$ratio of leaf sap ranged from 4 to 10 , whereas that of the secretion ranged from 24 to 56 . The ratio of $\mathrm{Cl}^{-}$vs the rest of anions remained around 3 in the leaf sap of salt-treated plants whereas it varied between 96 and 243 in the secretion. With increasing salinity higher secretion rates maintained the internal ion leaf concentration relatively low. The selective character of the secretion contributes to maintain favourable $\mathrm{Na}^{+} / \mathrm{K}^{+}$and $\mathrm{Cl}^{-} /$anion ratios in the leaf cells.

Key words: ion concentration, mangroves, $\mathrm{Na}^{+} / \mathrm{K}^{+}$ratio, salt stress, water relations

Efeitos da salinidade sobre a composição iônica foliar e taxa de secreção de sais em Avicennia germinans (L.) L.: Investigaram-se os efeitos da salinidade sobre as relações hídricas foliares e sobre a taxa e a composição iônica da secreção foliar em plantas de Avicennia germinans cultivadas sob condições controladas de salinidade. Incrementos de salinidade, de 0 a $940 \mathrm{~mol} \mathrm{NaCl} \mathrm{m}{ }^{-3}$, acarretaram reduções do potencial hídrico de antemanhã, de -0,56 a -4,16 MPa, e do potencial osmótico, de -2,27 a -4,48 MPa, enquanto o potencial de pressão permaneceu positivo nas plantas de todos os tratamentos. Em relação às plantas-controle, sob $940 \mathrm{~mol} \mathrm{NaCl} \mathrm{m}{ }^{-3}$, as concentrações de $\mathrm{Na}^{+}$e $\mathrm{Cl}^{-}$da seiva foliar aumentaram 19 e 7 vezes, respectivamente. Com a adição de sais, os principais íons acumulados nas folhas foram $\mathrm{Na}^{+} \mathrm{e}$ $\mathrm{Cl}^{-}$, enquanto nas plantas cultivadas sem sal íons $\mathrm{K}^{+}$acumularam-se nas folhas em extensão similar à dos íons $\mathrm{Na}^{+}$sob adição de sal. As taxas de secreção de $\mathrm{Na}^{+}$e $\mathrm{Cl}^{-}$aumentaram com o aumento da concentração externa de sal, sendo, sob $940 \mathrm{~mol} \mathrm{NaCl} \mathrm{m}{ }^{-3}$, respectivamente 59 e 46 vezes maiores em relação às das plantas-controle. O aumento da taxa de secreção contribuiu para contrabalançar o incremento da concentração de sais nas folhas. Nas plantas de todos os tratamentos que receberam sal, a razão $\mathrm{Na}^{+} / \mathrm{K}^{+}$da seiva foliar variou de 4 a 10, e de 24 a 56, na secreção. ${\mathrm{A} \mathrm{razão} \mathrm{Cl}^{-} /}^{\prime}$ demais ânions permaneceu em torno de 3 na seiva foliar das plantas tratadas com sal, enquanto na secreção essa razão variou de 96 a 243. Com o aumento da salinidade, maiores taxas de secreção permitiram a manutenção de concentrações iônicas relativamente baixas nas folhas. O caráter seletivo da secreção contribuiu para manter razões $\mathrm{Na}^{+} / \mathrm{K}^{+}$e $\mathrm{Cl}^{-} /$ ânions favoráveis nas células foliares.

Palavras-chave: concentração de íons, estresse salino, mangue, razão $\mathrm{Na}^{+} / \mathrm{K}^{+}$, relações hídricas 


\section{INTRODUCTION}

Mangrove species continuously incorporate salts from substrate and transport them to the leaves in the transpiration stream (Ball, 1988). Salt uptake helps to maintain positive pressure potential through their contribution to osmotic adjustment of growing tissues (Downton, 1982; Clough, 1984; Suárez and Sobrado, 2000). However, under high salinity conditions, the survival of the plant depends on its ability to regulate the internal salt concentrations and prevent ions from reaching toxic levels (Scholander et al., 1962; Atkinson et al., 1967; Ball, 1988). It has been shown that during water uptake, roots of some mangrove species exclude 80-95\% of the salt in the soil solution (Scholander et al., 1962; Atkinson et al., 1967). In addition, plants may regulate shoot ion concentration and reduce salt concentration in leaf tissue by other means such as salt secretion through leaf glands, succulence, and relocation of salt to other organs (Scholander et al., 1962; Atkinson et al., 1967; Leshem and Levinson, 1972; Sobrado, 2001).

In various mangrove species, salt is secreted by salt glands in the leaves, and their activity seems to be associated with the salinity of the nutrient solution. Thus, salt secretion contributes to eliminate the excess of salt reaching the leaves (Lüttge, 1971; Drennan and Pammeter, 1982; Waisel et al., 1986; Sobrado, 2001). The activity of salt glands is highly selective, secreting mostly $\mathrm{NaCl}$ and thus contributing to maintain a favorable $\mathrm{K}^{+} / \mathrm{Na}^{+}$ratio in the leaf cells (Waisel et al., 1986; Sobrado and Greaves, 2000). However, other ions such as $\mathrm{K}^{+}, \mathrm{Mg}^{2+}, \mathrm{Ca}^{2+}$ and $\mathrm{SO}_{4}^{2-}$ can be present in the secreted solution (Scholander et al., 1962; Atkinson et al., 1967; Rozema et al., 1981; Boon and Allaway, 1986; Sobrado and Greaves, 2000). Thus, secretion regulates internal salt concentrations and contributes to build specific ionic ratios favorable for the maintenance of the metabolic activity of leaf cells (Atkinson et al., 1967; Lüttge, 1971; Rozema et al., 1981; Popp et al., 1985; Waisel et al., 1986). The quality and quantity of the salt taken up and secreted varies widely, depending on soil salinity and species (Albert and Popp, 1977). As in other mangrove species, in Avicennia germinans, the leaf secretion rate increases with soil salinity. In this species, the secretion solution contains essential macronutrients such as K, Ca and S, and micronutrients such as Zn (Sobrado and Greaves, 2000).
In the numerous papers dealing with salt secretion in Avicennia species, several aspects have received contradictory reports: (i) succulence does not increase with salinity of the nutrient solution and has little significance for regulation of leaf salt concentrations (Tomlinson, 1986) or tends to increase, contributing with salt regulation (Suárez and Sobrado, 2000), or tends to decrease under hypersaline conditions (Sobrado, 2001); (ii) the rate of salt secretion increases with salinity (Ball, 1988) or tends to saturate following a sigmoid pattern in plants grown under hypersaline conditions (Sobrado, 2001); and (iii) the rate of salt secretion appears to be nearly constant (Scholander et al., 1962; Sobrado, 2001) or to vary diurnally (Drennan and Pammeter, 1982; Waisel et al., 1986). In the present study we, therefore, reevaluate previous findings by performing a full assessment of the effect of salinity on the rate and ionic composition of leaf secretion in plants of a mangrove species, A. germinans growing under controlled salinity conditions, in addition to comparing these parameters with salt composition of the secreting leaves. The importance and physiological relevance of the secretion for the maintenance of the internal concentrations of leaf ions, as well as the role of selective ion secretion on leaf ion ratios were examined.

\section{MATERIALS AND METHODS}

Plant materials: Avicennia germinans (L.) L. propagules with a fresh mass of $1.90 \pm 0.37 \mathrm{~g}$ were collected in Cumaná $\left(10^{\circ} 27^{\prime} \mathrm{N}, 64^{\circ} 10^{\prime} \mathrm{W}\right)$, Venezuela, and planted in 2.5 L pots filled with washed sand. Seedlings were maintained under well-watered conditions for 18 weeks, by placing the pots in $7 \mathrm{~cm}$ deep trays filled with $40 \%$ Hoagland nutrient solution. After that, the seedlings were separated into five groups of 20 plants each and marine salt was added to the nutrient solution, increasing the concentration at a rate of $\approx 15 \mathrm{~mol} \mathrm{NaCl} \mathrm{m} \mathrm{m}^{-3}$ per day until obtaining five salinity treatments: 0, 170, 430, 680, and $940 \mathrm{~mol} \mathrm{NaCl} \mathrm{m}{ }^{-3}$, corresponding to salinities of 15 , 25, 40 and 55\% as measured with a refractometer calibrated for $\mathrm{NaCl}$. Marine salt was preferred to pure $\mathrm{NaCl}$ because it simulates the effect of salinity under natural conditions. Each group of plants, corresponding to a treatment, was connected in series to a $200 \mathrm{~L}$ tank, with Hoagland's nutrient solution at $40 \%$ strength. The 
saline solutions were constantly recycled through the tank by means of pumps. This system allowed solution aeration and effectively counteracted slight increases in salinity of the solution at midday, when transpiration peaked. The nutrient solution in each tank was replaced every three weeks and salinity adjusted. Plants grown at $0 \mathrm{~mol} \mathrm{~m}^{-3}$ salinity were used as controls. The plants were grown under these treatments in a greenhouse for 16 months under natural light with $\mathrm{a} \approx 12 \mathrm{~h}$ photoperiod. Throughout the growing period, temperatures averaged $30.5 \pm 3.4^{\circ} \mathrm{C}$ during the day and $16.3 \pm 2.0^{\circ} \mathrm{C}$ at night, and the relative humidity oscillated between 50 and $78 \%$. Maximum level of photosynthetically active radiation along the experiment was $1550 \pm 370 \mu \mathrm{mol} \mathrm{m}^{-2} \mathrm{~s}^{-1}$.

Leaf water relations: Measurements began 11 months after applying the treatments, when leaves had developed under each particular salinity treatment. Predawn water potential $\left(\Psi_{w}\right)$ was measured in five randomly selected plants for each treatment using a pressure chamber (model 3000, Soil Moisture Equipment Corp., CA, USA). Opposite leaves to those selected for $\Psi_{w}$ measurement in each plant were detached, rinsed with distilled water and dried with soft tissue paper to eliminate salt from the surface. After eliminating the middle vein, the blade was placed in a syringe and frozen in liquid nitrogen. The frozen samples were thawed during $30 \mathrm{~min}$ at room temperature before sap extraction to determine leaf osmolality with a vapor pressure osmometer (model 5500, Wescor, Logan, UT, USA). The osmolality values were transformed to solute potential $\left(\Psi_{s}\right)$ at $25^{\circ} \mathrm{C}$ and used to calculate pressure potential $\left(\Psi_{\mathrm{p}}\right)$. The solute potential of the saline nutrient solution $\left(\Psi_{\text {sol }}\right)$ was determined simultaneously and in the same way as $\Psi_{s}$.

The same leaves used to determine leaf secretion per leaf area and fresh weight unit were used to determine leaf succulence in each salinity treatment. Leaf succulence (water content per unit area) was determined in ten fully expanded leaves from each of five plants from each treatment. Leaves were detached before dawn; the area of each leaf was measured immediately, then it was rinsed with distilled water to remove salt deposits and gently dried with tissue paper. Clean leaves were weighed to determine fresh mass $\left(\mathrm{M}_{\mathrm{f}}\right)$, dried for $48 \mathrm{~h}$ at $70^{\circ} \mathrm{C}$ and weighed again to determine dry mass $\left(\mathrm{M}_{\mathrm{d}}\right)$. The leaf water content $\left(W_{c}=M_{f}-M_{d}\right)$ was then calculated on a leaf area and dry mass basis.
Two months before determination of the secretion rate, the transpiration rate was measured in 15-30 intact and fully expanded leaves taken from seven to ten plants per treatment, with an open system (Licor-6400, Licor Inc., NE, USA). The chamber temperature was kept at $27^{\circ} \mathrm{C}$ and the vapor pressure deficit varied between 1.3 to $2.9 \mathrm{kPa}$. Relative humidity was kept at ambient level and $\mathrm{CO}_{2}$ concentration adjusted to $380 \mu \mathrm{mol} \mathrm{mol}{ }^{-1}$.

Secretion rate and concentration of ions in leaf and secreted solution: Twelve months after applying the treatments, one leaf from each of five plants randomly selected within each treatment was used to assess leaf salt secretion, as documented previously by Sobrado (2001). All leaves were young, fully expanded, and corresponded to the third pair of leaves in the branch. They were thoroughly rinsed with distilled water to remove from the surface all salt previously secreted. After $12 \mathrm{~h}$ the leaves were rinsed with $25 \mathrm{~mL}$ deionized/distilled water to remove all salt deposits just prior to the onset of the photoperiod $(0600 \mathrm{~h}$ ), and rinsed again $12 \mathrm{~h}$ later at the conclusion of the photoperiod (1800 h). Thereafter, leaf area and ion concentrations in the leaf washings were determined. We measured cations $\left(\mathrm{Na}^{+}, \mathrm{K}^{+}, \mathrm{Ca}^{2+}\right.$ and $\mathrm{Mg}^{2+}$ ) by atomic absorption spectrophotometry (Varian AA-6, Varian Techtron, CA, USA), and anions $\left(\mathrm{Cl}^{-}, \mathrm{NO}_{3}^{-}\right.$, $\mathrm{SO}_{4}{ }^{2-}$ and oxalate) by ion chromatography (Dionex DX100, Dionex Corp., CA, USA). Finally, diurnal and nocturnal secretion rates per unit leaf area were calculated.

The experiment was repeated two months later, when 10 leaves from each of five plants from each treatment were sampled. The plants used in this second experiment were the same used previously and the selected leaves were similar (third pair of leaves) to those used to determine secretion rates. In this second experiment, we measured the secretion rate per unit leaf area during $24 \mathrm{~h}$ in one leaf from each of five plants from each treatment and then detached the leaves to measure the internal ion concentration. Data for the secretion rate over a period of $24 \mathrm{~h}$, from both experiments, were pooled since differences between them were not significant. Leaf Mf was determined after eliminating the middle veins. Afterwards, leaf samples were dried in a ventilated oven $\left(60^{\circ} \mathrm{C}, 48 \mathrm{~h}\right)$ and weighed. Ions were extracted (watersoluble fraction) from $100 \mathrm{mg}$ of ground leaf material with 
boiling distilled water for $1 \mathrm{~h}$. Water extracts were analyzed for cations $\left(\mathrm{Na}^{+}, \mathrm{K}^{+}, \mathrm{Ca}^{2+}\right.$ and $\left.\mathrm{Mg}^{2+}\right)$ and anions $\left(\mathrm{Cl}^{-}, \mathrm{NO}_{3}^{-}, \mathrm{SO}_{4}{ }^{2-}\right.$ and oxalate $)$ as described above. The ion concentration was expressed on a molar basis per mass of water in fresh tissue. The total inorganic ion concentration was used to calculate their contribution to leaf $\Psi_{\mathrm{s}}$ by using the van't Hoff relationship.

Data analysis: The statistical significance of the differences between diurnal and nocturnal secretion rates was tested using Student's $t$-test. Differences in the ion composition of secretion and leaves between salinity treatments were tested using a one-way ANOVA test and an a posteriori test (Least significant difference, LSD). In the case of heterogeneous variances, we used Dunnet's T3 test. Differences between leaves secreting for 12 and $24 \mathrm{~h}$ were tested by a paired $t$-test, for each salinity level. A significance value of $P<0.05$ was used throughout. Details of the statistical procedures followed Sokal and Rohlf (1969).

\section{RESULTS AND DISCUSSION}

Leaf water relations: As salinity increased from 0 to 940 $\mathrm{mol} \mathrm{NaCl} \mathrm{m}{ }^{-3}$, predawn water potential $\left(\Psi_{\mathrm{w}}\right)$ and leaf sap solute potential $\left(\Psi_{\mathrm{s}}\right)$ decreased from -0.56 to -4.16 MPa and from -2.27 to $-4.48 \mathrm{MPa}$, respectively (Figure 1). These decreases with increasing salinity are within the range of values published for $A$. germinans and other mangrove species growing under similar salinity conditions (Scholander et al., 1962; Rada et al., 1989; Suárez and Sobrado, 2000; Sobrado, 2001). In all cases, the differences in $\Psi_{w}$ between plant and saline nutrient solution varied between -0.6 and -1.0 MPa in plants growing from 0 to $430 \mathrm{~mol} \mathrm{NaCl} \mathrm{m}^{-3}$, allowing water uptake by the roots (Scholander et al., 1962). However, $\Delta \Psi$ between plant and saline nutrient solution decreased dramatically at 680 and $940 \mathrm{~mol} \mathrm{NaCl} \mathrm{m}^{-3}$, suggesting that at these levels of salinity leaves reached their limit of ion accumulation capacity. As a consequence of the osmotic adjustment, the pressure potential $\left(\Psi_{\mathrm{p}}\right)$ remained positive in the morning under all salinity treatments, although close to zero in plants cultivated at $940 \mathrm{~mol} \mathrm{NaCl} \mathrm{m}^{-3}(0.40$ MPa; Figure 1). In the same species grown in salinities of 0-550 $\mathrm{mol} \mathrm{NaCl} \mathrm{m}{ }^{-3}, \Psi_{\mathrm{p}}$ at predawn was about 1.0 MPa (Suárez and Sobrado, 2000). However, at midday, when $\Psi_{\mathrm{w}}$ reached its minimum, $\Psi_{\mathrm{p}}$ approached zero $(<0.15 \mathrm{MPa}$;
Suárez and Sobrado, 2000; Sobrado, 2001). These results suggest that $A$. germinans under high salinity may not maintain a constant $\Psi_{\mathrm{p}}$ throughout the day due, at least partially, to limitations in diurnal osmotic adjustment.

Leaf $\Psi_{s}$ may decrease as a consequence of either an accumulation of solutes or a decrease in cell water content. Thus, some species may develop succulence to various levels in order to maintain a suitable $\Psi_{s}$ (Waisel, 1972). In mangrove species it has been reported that a progressive increase in $\mathrm{Na}^{+}$and $\mathrm{Cl}^{-}$concentration per unit leaf area is almost quantitatively compensated by a similar increase in the leaf water content $\left(\mathrm{W}_{\mathrm{c}}\right)$, the ion concentration per unit of leaf water thus remaining almost constant (Jennings, 1976; Suárez and Sobrado, 2000). In this study $W_{c}$ per unit leaf area increased by $34 \%$ when salinity changed from 0 to $170 \mathrm{~mol} \mathrm{NaCl} \mathrm{m}^{-3}$, but further

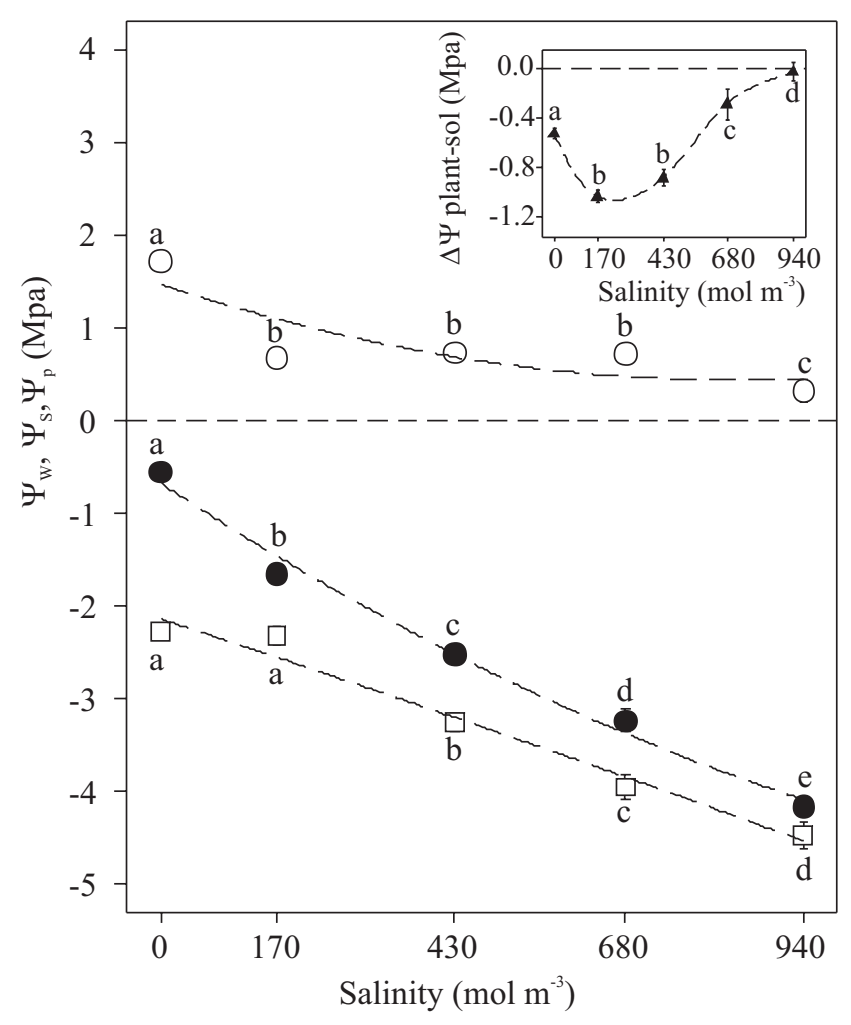

Figure 1. Leaf water potential $\left(\Psi_{w}, \bullet\right)$, solute potential $\left(\Psi_{s}, \square\right)$ and pressure potential $\left(\Psi_{p}, \bigcirc\right)$ in leaves from Avicennia germinans plants grown at $0,170,430,680$ and $940 \mathrm{~mol} \mathrm{NaCl} \mathrm{m}^{-3}$. The inset shows the difference between plant and solution water potential $\left(\Delta \Psi_{\text {plant-sol }}\right)$ for each salinity treatment. Points are averages and bars correspond to SE $(n=5)$. Different letters indicate significant differences among salinity concentrations at $P<0.05$. 
increases in salinity did not augment leaf succulence (Figure 2). Leaf $\mathrm{W}_{\mathrm{c}}$ on an area basis ranged from 265 to $375 \mathrm{~g} \mathrm{~m}^{-2}$, values similar to those obtained for the same (Suárez and Sobrado, 2000; Sobrado, 2001) and other (Ball et al., 1988; Parida et al., 2004) mangroves species. However, maximum succulence has been previously reported in plants growing at $340 \mathrm{~mol} \mathrm{~m}^{-3}$ (Suárez and Sobrado, 2000) and $428 \mathrm{~mol} \mathrm{~m}^{-3}$ (Sobrado, 2001). Differences in the salinity at which maximum $\mathrm{W}_{\mathrm{c}}$ has been observed may be a result of the leaf sampling methods. In this study we used whole leaves, whilst Suárez and Sobrado (2000) sampled disks of the leaf blades and Sobrado (2001) corrected the $\mathrm{W}_{\mathrm{c}}$ per unit leaf area by the relative proportion of symplastic water. In contrast, with the effect of salinity on $\mathrm{W}_{\mathrm{c}}$, leaf ion per unit area followed a decreasing exponential curve, attaining 104\% from 0 to $940 \mathrm{~mol} \mathrm{NaCl} \mathrm{m}{ }^{-3}$. As a result, ion concentration per unit leaf water increased steadily with salinity, in contrast to the behavior observed in this species by Sobrado (2001).
Leaf $\mathrm{W}_{\mathrm{c}}$ on a dry mass and leaf area basis showed a similar tendency, because the leaf dry mass/area ratio was not affected by salinity and averaged at $140 \pm 16 \mathrm{~g} \mathrm{~m}^{-2}$. As a result of increased ion accumulation with salinity, when ion mass was subtracted from leaf dry mass, $\mathrm{W}_{c}$ on the basis of dry mass showed an increase from 8 to 13\% with a salinity increase from 0 to $940 \mathrm{~mol} \mathrm{NaCl} \mathrm{m}^{-3}$ (Figure 2; inset).

Leaf ion concentration: In all salt treatments, the main ions accumulated were $\mathrm{Na}^{+}$and $\mathrm{Cl}^{-}$, representing 76-96 and $76-84 \%$ of all cations and anions present in leaves, respectively. In general, leaf $\mathrm{Na}^{+}$and $\mathrm{Cl}^{-}$concentrations increased with salinity, but $\mathrm{Na}^{+}$concentrations stabilized at $680 \mathrm{~mol} \mathrm{~m}$, whereas $\mathrm{Cl}^{-}$remained similar at intermediate salinity and increased markedly at the highest salinity treatment (Table 1 ). The plants grown without salt added accumulated $\mathrm{K}^{+}$in leaves at levels similar to those of $\mathrm{Na}^{+}$in the salt treatments. This allows

Table 1. Cation and anion concentration and secretion rate in leaves of A. germinans plants growing under controlled salinity conditions. Salt secretion rates were estimated for a $24 \mathrm{~h}$ period with a $12 \mathrm{~h}$ photoperiod. Different letters indicate significant differences at $P<0.05 . n=10 \pm$ SD.

\begin{tabular}{|c|c|c|c|c|c|c|}
\hline \multicolumn{7}{|c|}{ Leaf concentration $\left(\mathrm{mol} \mathrm{m}^{-3}\right)$} \\
\hline \multicolumn{2}{|c|}{ Salinity $\left(\mathrm{mol} \mathrm{m}^{-3}\right)$} & 0 & 170 & 430 & 680 & 940 \\
\hline $\mathrm{Na}^{+}$ & \multicolumn{2}{|c|}{$31.65 \pm 18.73 \mathrm{a}$} & $433.3 \pm 54.7 \mathrm{~b}$ & $511.2 \pm 42.2 \mathrm{c}$ & $620.3 \pm 78.6 \mathrm{~d}$ & $616.7 \pm 44.6 \mathrm{~d}$ \\
\hline $\mathrm{K}^{+}$ & \multicolumn{2}{|c|}{$529.27 \pm 176.14 \mathrm{a}$} & $112.26 \pm 35.46 b$ & $51.00 \pm 27.38 \mathrm{c}$ & $61.67 \pm 9.93 c$ & $103.78 \pm 33.27 \mathrm{~b}$ \\
\hline $\mathrm{Mg}^{2+}$ & \multicolumn{2}{|c|}{$146.06 \pm 59.25 \mathrm{a}$} & $21.61 \pm 12.12 b$ & $13.73 \pm 3.74 b$ & $9.48 \pm 1.33 b$ & $4.46 \pm 2.11 \mathrm{c}$ \\
\hline $\mathrm{Ca}^{2+}$ & \multicolumn{2}{|c|}{$7.69 \pm 3.2 \mathrm{a}$} & $6.82 \pm 3.20 \mathrm{a}$ & $7.17 \pm 2.49$ a & $5.42 \pm 2.30 \mathrm{a}$ & $7.76 \pm 2.10 \mathrm{a}$ \\
\hline $\mathrm{Cl}^{-}$ & \multicolumn{2}{|c|}{$68.31 \pm 13.22 \mathrm{a}$} & $185.77 \pm 51.77 \mathrm{~b}$ & $132.01 \pm 18.11 b$ & $201.46 \pm 65.60 \mathrm{~b}$ & $450.57 \pm 69.51 \mathrm{c}$ \\
\hline $\mathrm{SO}_{4}^{2-}$ & \multicolumn{2}{|c|}{$31.05 \pm 6.47 \mathrm{a}$} & $6.31 \pm 3.45 b$ & $4.45 \pm 2.29 \mathrm{~b}$ & $4.26 \pm 1.17 \mathrm{~b}$ & $3.18 \pm 2.16 \mathrm{~b}$ \\
\hline $\mathrm{NO}_{3}^{-}$ & \multicolumn{2}{|c|}{$8.02 \pm 1.69$ a } & $10.05 \pm 3.49$ a & $7.32 \pm 1.36 \mathrm{a}$ & $9.55 \pm 2.11 \mathrm{a}$ & $22.30 \pm 3.79 b$ \\
\hline $\mathrm{PO}_{4}^{2-}$ & \multicolumn{2}{|c|}{$8.95 \pm 5.30 \mathrm{a}$} & $5.62 \pm 2.97 \mathrm{a}$ & $5.43 \pm 1.90 \mathrm{a}$ & $10.26 \pm 3.75 \mathrm{a}$ & $20.74 \pm 5.83 b$ \\
\hline Oxalate & \multicolumn{2}{|c|}{$36.62 \pm 12.81 \mathrm{a}$} & $36.58 \pm 15.15 \mathrm{a}$ & $23.38 \pm 5.50 \mathrm{~b}$ & $31.94 \pm 14.58 \mathrm{ab}$ & $36.99 \pm 1.60 \mathrm{a}$ \\
\hline \multicolumn{7}{|c|}{ Secretion rate $\left(\mathrm{mmol} \mathrm{m}^{-2} \mathrm{~d}^{-1}\right)$} \\
\hline $\mathrm{Na}^{+}$ & \multicolumn{2}{|c|}{$0.55 \pm 0.23 \mathrm{a}$} & $9.06 \pm 3.20 b$ & $14.17 \pm 5.34 \mathrm{c}$ & $21.36 \pm 8.34 \mathrm{~cd}$ & $32.64 \pm 14.71 \mathrm{~d}$ \\
\hline $\mathrm{K}^{+}$ & \multicolumn{2}{|c|}{$0.25 \pm 0.19 \mathrm{a}$} & $0.37 \pm 0.19 \mathrm{a}$ & $0.38 \pm 0.19 \mathrm{a}$ & $0.38 \pm 0.23 \mathrm{a}$ & $0.81 \pm 0.29 b$ \\
\hline $\mathrm{Mg}^{2+}$ & \multicolumn{2}{|c|}{$0.26 \pm 0.10 \mathrm{a}$} & $0.22 \pm 0.09 \mathrm{a}$ & $0.14 \pm 0.07 \mathrm{~b}$ & $0.12 \pm 0.05 b$ & $0.19 \pm 0.07 \mathrm{ab}$ \\
\hline $\mathrm{Ca}^{2+}$ & \multicolumn{2}{|c|}{$0.34 \pm 0.16 \mathrm{a}$} & $0.67 \pm 0.28 \mathrm{~b}$ & $0.48 \pm 0.23 \mathrm{ab}$ & $0.55 \pm 0.12 \mathrm{~b}$ & $0.62 \pm 0.25 b$ \\
\hline $\mathrm{Cl}^{-}$ & \multicolumn{2}{|c|}{$1.21 \pm 0.35 \mathrm{a}$} & $15.35 \pm 5.50 \mathrm{~b}$ & $19.74 \pm 7.34$ bc & $27.97 \pm 9.01 \mathrm{c}$ & $55.93 \pm 21.01 \mathrm{~d}$ \\
\hline $\mathrm{SO}_{4}^{2-}$ & \multicolumn{2}{|c|}{$0.11 \pm 0.06 \mathrm{a}$} & $0.16 \pm 0.13 \mathrm{ab}$ & $0.09 \pm 0.06 \mathrm{a}$ & $0.16 \pm 0.08 \mathrm{ab}$ & $0.23 \pm 0.12 \mathrm{~b}$ \\
\hline $\mathrm{NO}_{3}^{-}$ & \multicolumn{2}{|c|}{$<0.03$} & $<0.03$ & $<0.02$ & $<0.05$ & $<0.08$ \\
\hline $\mathrm{PO}_{4}^{2-}$ & \multicolumn{2}{|c|}{$<0.02$} & $<0.02$ & $<0.04$ & $<0.04$ & $<0.04$ \\
\hline Oxalate & \multicolumn{2}{|c|}{$<0.01$} & $<0.02$ & $<0.02$ & $<0.01$ & $<0.03$ \\
\hline
\end{tabular}




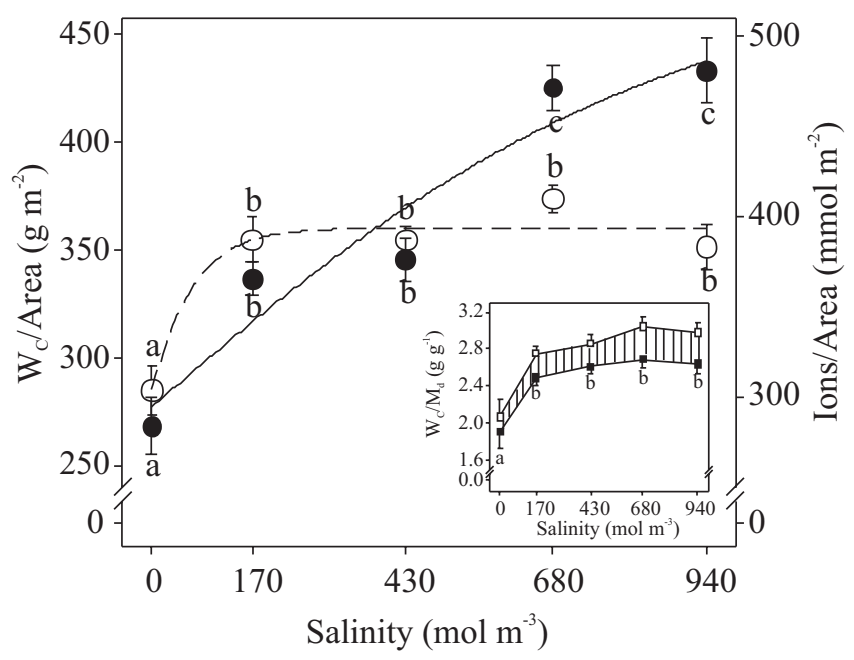

Figure 2. Water content $\left(\mathrm{W}_{c}, \bigcirc\right)$ and total ions $(\bullet)$ per unit leaf area in leaves from Avicennia germinans plants grown at $0,170,430,680$ and $940 \mathrm{~mol} \mathrm{NaCl} \mathrm{m}{ }^{-3}$. The inset shows the $\mathrm{W}_{\mathrm{c}}$ per unit dry mass when ion mass was included ( $\square$ ) or eliminated $(\square)$. Points are averages and bars correspond to SE $(n=10)$. Different letters indicate significant differences at $P<0.05$.

us to explain the capability of these species to grow successfully and to maintain a positive $\Psi_{\mathrm{p}}$ in low-salinity environments (Suárez and Medina, 2006). In plants cultivated with added salt, the $\mathrm{Na}^{+} / \mathrm{K}^{+}$ratio ranged from 4 to 10 and tended to increase only slightly with increasing salinity (Figure 3A). Similar $\mathrm{Na}^{+} / \mathrm{K}^{+}$ratios (7-25) were measured in mature leaves of mangrove species grown under controlled and natural conditions at lower salinity levels (Atkinson et al., 1967; Clough, 1984; Ball, 1988; Paliyavuth et al., 2004; Parida et al., 2004). Potassiumsodium selective ratios $\left(\mathrm{S}_{\mathrm{K}, \mathrm{Na}}\right)$, computed from $\mathrm{K}_{\text {plant }}^{+}$' $\mathrm{Na}^{+}{ }_{\text {plant }} \div \mathrm{K}^{+}{ }_{\text {water }} / \mathrm{Na}^{+}{ }_{\text {water }}$ (Pitman, 1977), for plants growing in presence of salt ranged from 4.5 to 16.5 and were similar to the values reported for other mangrove species (Dowton, 1982; Clough, 1984; Paliyavuth, 2004). The capability of $A$. germinans to take up $\mathrm{K}^{+}$efficiently even in high-salinity environments may be regulated by the $\mathrm{K}^{+}$transporter (Trk/ HKT) family (Gierth and Mäser, 2007). Anyway, the values of $\mathrm{S}_{\mathrm{K}, \mathrm{Na}}$ obtained for plants growing at $0 \mathrm{~mol} \mathrm{NaCl} \mathrm{m}^{-3}$ was considerably higher than those reported previously (16.5 vs 0.5; Downton, 1982; Clough, 1984).

Leaf $\mathrm{Mg}^{2+}$ decreased with salinity while $\mathrm{Ca}^{2+}$ concentrations were below $8 \mathrm{~mol} \mathrm{~m}^{-3}$, so that their contribution to the inorganic ion composition of the leaf was negligible at all salinities. Similar results have been obtained in A. marina (Downton, 1982) and other halophytes (Marcum and Murdoch, 1992; Paliyavuth et al., 2004). Nitrate, phosphate, sulfate and oxalate remained relatively constant with salinity (Table 1). Other studies indicate that these ions only change with leaf age (Popp et al., 1985). In control plants $\mathrm{K}^{+}$and $\mathrm{Mg}^{2+}$ were the main cations (74 \pm 9 and $19 \pm 6 \%$, respectively), and $\mathrm{Cl}^{-}$ and $\mathrm{SO}_{4}{ }^{2-}$ the main anions $(45 \pm 5$ and $20 \pm 6 \%$, respectively) accumulated in leaves (Table 1 ).

In plants grown with added salt, $\mathrm{Cl}^{-}$concentrations in leaves were always lower than the corresponding $\mathrm{Na}^{+}$ concentration $(\mathrm{Na} / \mathrm{Cl}>1$; Figure $3 \mathrm{C})$. This has also been reported for Rhizophora stylosa (Clough, 1984) and A. marina (Downton, 1982). Cation/anion ratios were always above 1 (Figure 3D). Similarly, Clough (1984) reported that leaf tissues of two mangrove species grown under saline conditions accumulated 1.7-2.7 times more cations than chloride. These ratios indicate that ion balance should be attained by the contribution of organic anions in addition to oxalate (Albert and Popp, 1977; Popp et al., 1985).

Leaf secretion rates: Salt secretion rates increased steadily with salinity (Table 1 ). We did not detect significant differences between day and night, although there was a tendency towards higher rates during the night period (Figure 4). The absence of a diurnal rhythm in secretion rates has been reported for the mangrove species A. germinans, Aegiceras corniculatum and A. marina (Scholander et al., 1962; Waisel et al., 1986; Sobrado, 2001). However, Drennan and Pammeter (1982) observed higher nocturnal rates in A. marina.

Secretion rates found in leaves rinsed once or twice during a $24 \mathrm{~h}$ period were not statistically different (Figure 4). For A. marina (Boon and Allaway, 1982) and the halophyte Glaux maritima (Rozema and Riphagen, 1977) higher rates of secretion were obtained when calculated over short periods (minutes), but both studies reported steady secretion rates from about $2 \mathrm{~h}$ after washing.

The secretion rates of $\mathrm{Na}^{+}$and $\mathrm{Cl}^{-}$increased linearly with salinity $\left(r^{2}=0.98\right.$ for $\mathrm{Na}^{+}$and 0.91 for $\left.\mathrm{Cl}^{-}\right)$. As salinity went from 0 to $940 \mathrm{mM} \mathrm{NaCl} \mathrm{m}{ }^{-3}$ the secretion rate grew 34 times, whereas ions accumulated per unit leaf area increased only 1.7 times (Table 1 ). In addition, the rates of secretion of both $\mathrm{Na}^{+}$and $\mathrm{Cl}^{-}$were related to the concentration of these ions in the leaf sap $\left(r^{2}=0.86\right.$ for $\mathrm{Na}^{+}$ 


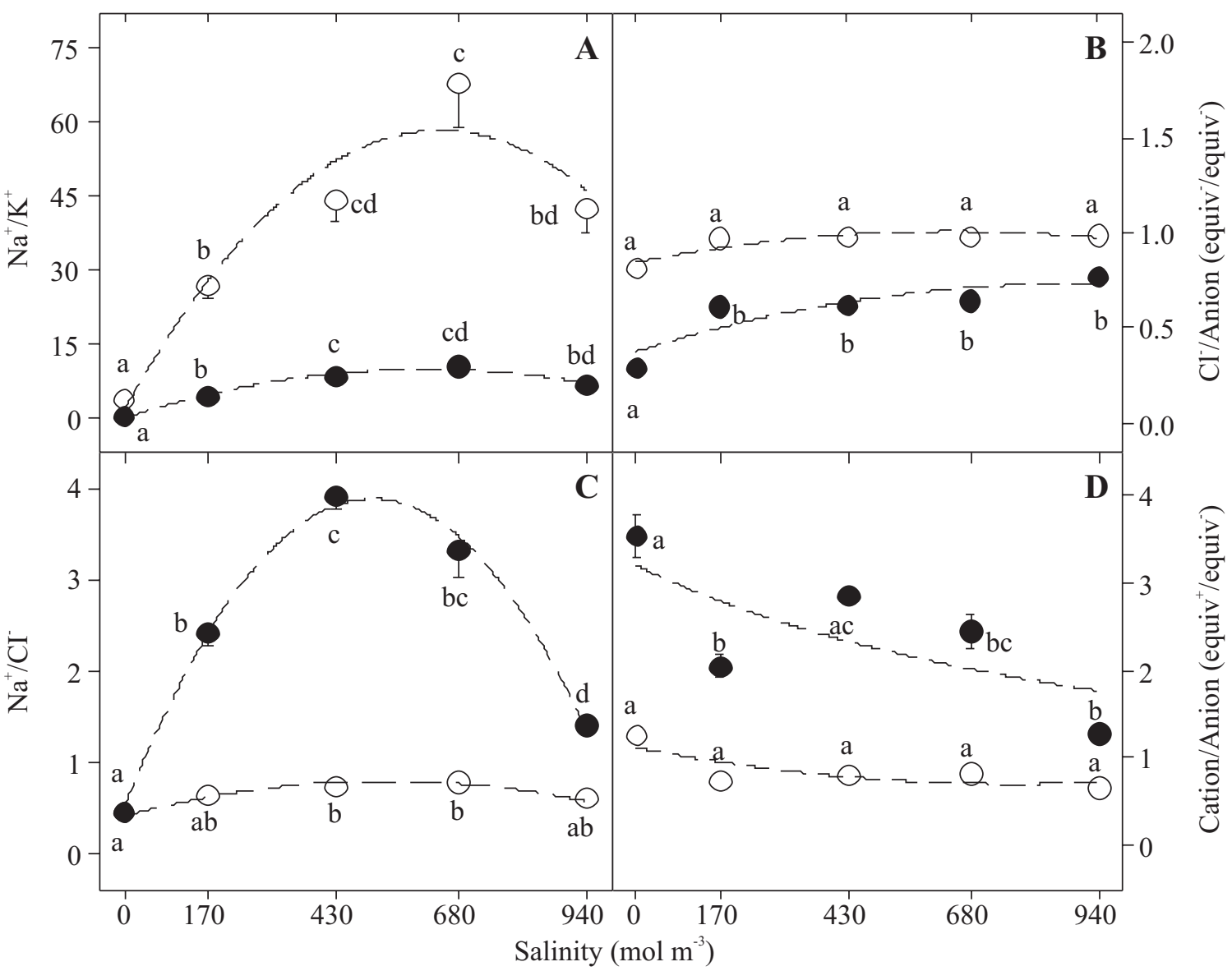

Figure 3. (A) $\mathrm{Na}^{+} / \mathrm{K}^{+}$, (B) $\mathrm{Cl}^{-} /$(total anion), (C) $\mathrm{Cl}^{-} / \mathrm{Na}^{+}$and (D) cation/anion ratios in the solution containing secreted salt $(\bigcirc)$ and in leaf sap $(\bullet)$ from Avicennia germinans plants grown at 0, 170, 430, 680 and $940 \mathrm{~mol} \mathrm{NaCl} \mathrm{m}{ }^{-3}$. Cation/anion ratios were expressed as equivalents of each ion. Salt secretion rate was estimated for a $24 \mathrm{~h}$ period. Different letters indicate significant differences at $P<0.05 . n=10 \pm$ SE.

and 0.97 for $\mathrm{Cl}^{-}$). In all cases, $\mathrm{Cl}^{-}$secretion was greater than $\mathrm{Na}^{+}$secretion. It seems, then, that increased secretion rates counteracted partially the accumulation of salts transported into the leaves by the transpiration stream. The salt secretion rates in A. germinans found in this study are within the range previously reported in A. germinans (Sobrado and Greaves, 2000; Sobrado, 2001) and other mangrove species (3-75 $\mathrm{mmol} \mathrm{m}^{-2} \mathrm{~d}^{-1}$; Scholander et al., 1962; Drennan and Pammenter, 1982; Ball, 1988).

Our results indicated that the salt secretion process is not saturated within the range of salinities applied. This result differs from those of Sobrado (2001) who found in the same species a slight decrease in secretion rate at salinities above $600 \mathrm{~mol} \mathrm{NaCl} \mathrm{m}^{-3}$. However, Rozema et al. (1981) found in several halophytic species a decrease in secretion rate above $100 \mathrm{mM} \mathrm{NaCl}$. In any case, our results document the high salt secretion capability of $A$. germinans leaves that explains its tolerance to hypersaline conditions (Tomlinson, 1986). In A. germinans, a greater secretion rate at higher salinity may be related to increased activity of leaf salt secreting glands, because these remained constant at 26-28 glands $\mathrm{mm}^{-2}$ and $15-18$ glands $\mathrm{mm}^{-2}$ in adaxial and abaxial surfaces, respectively, in plants cultivated in the greenhouse at different salinities (N. Suárez, unpublished results).

Leaf transpiration rate was $5.9 \pm 1.3,4.5 \pm 1.1,2.6 \pm 1.3$ and $1.3 \pm 0.5 \mathrm{mmol} \mathrm{m}^{-2} \mathrm{~s}^{-1}$ at $170,430,680$ and $940 \mathrm{~mol} \mathrm{NaCl}$ $\mathrm{m}^{-3}$, respectively. Using these values and assuming that all salt being transported in the xylem ends up in the leaves and that in an adult leaf all of this salt is secreted (in mature leaves, salt content is practically constant), we estimated for each salinity treatment that xylem 


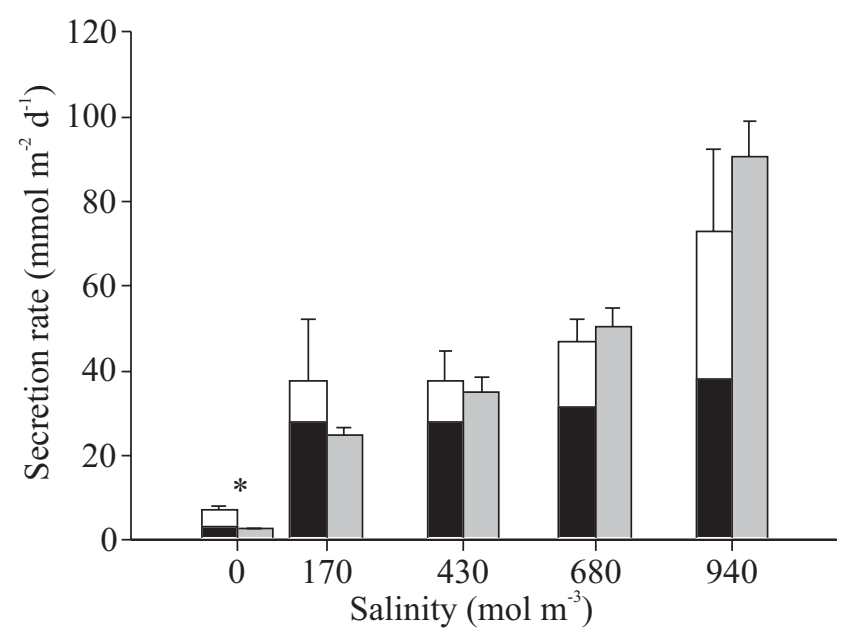

Figure 4. Nocturnal (dark), diurnal (white) and whole day (grey) ion secretion rates in leaves from Avicennia germinans plants grown at 0, 170, 430, 680 and $940 \mathrm{~mol}$ $\mathrm{NaCl} \mathrm{m} \mathrm{m}^{-3}$. Salt secretion rates were estimated for $12 \mathrm{~h}$ (nocturnal or diurnal) and $24 \mathrm{~h}$ (whole day) periods. Cations $\left(\mathrm{Na}^{+}+\mathrm{K}^{+}+\mathrm{Mg}^{2+}+\mathrm{Ca}^{2+}\right)$ and anions $\left(\mathrm{Cl}^{-}, \mathrm{SO}_{4}{ }^{2-}\right.$, $\mathrm{NO}_{3}^{-}, \mathrm{PO}_{4}{ }^{2-}$ and oxalate). Bars are averages. An asterisk indicates significant differences between secretion rates estimated for periods of 12 and $24 \mathrm{~h}(P<0.05 ; n=5 \pm$ SE).

osmolality represents approximately 3-9\% of that in the external solution. These values are similar to those reported previously by Scholander et al., (1962) and Ball (1988). We estimated that the time required for a leaf to reach the measured concentration in each salinity treatment decreased from 72 to 29 days as salinity increased from 0 to $940 \mathrm{~mol} \mathrm{NaCl} \mathrm{m}{ }^{-3}$. This time is reasonable considering that the half-life of a leaf in $A$. germinans decreases from 425 to 96 days under the same salinity treatments (Suárez and Medina, 2005). Therefore, transpiring leaves of $A$. germinans do accumulate large amounts of ions during their expansion and secretion rates are enough to maintain adequate physiological levels of salt in the mature leaf (Atkinson et al., 1967; Ball, 1988). However, after leaf maturity is reached and at high salinity, the rate of salt transport to the leaf may not be compensated by the secretion rate and leaf senescence would be accelerated.

Ion composition of the secretion: The main ions secreted were $\mathrm{Na}^{+}$and $\mathrm{Cl}^{-}$. Similar results were reported for $A$. marina (Boon and Allaway, 1986), A. germinans (Sobrado and Greaves, 2000), and other salt secreting halophytes
(Atkinson et al., 1967; Rozema et al., 1981). Although $\mathrm{Cl}^{-}$ concentrations in leaf sap was lower than those of $\mathrm{Na}^{+}$, rates of secretion of the former were much higher (Table 1).

Sodium secretion rate increased with salinity, whereas that of $\mathrm{K}^{+}$remained relatively constant in treatments with salt added. Then, the $\mathrm{Na}^{+} / \mathrm{K}^{+}$ratio of the secretion increased significantly with salinity, up to 6-7 times above the ratios in the leaf (Figure 3A). While the $\mathrm{Na}^{+} / \mathrm{K}^{+}$ ratio in the nutrient solution increased from 37 to 97 between 170 to $940 \mathrm{~mol} \mathrm{~m}^{-3}$, it only increased by 4-10 in the leaf and 28-68 in the secretion. Atkinson et al. (1967) reported similar results for other salt-secreting halophytes. In addition to $\mathrm{Na}^{+}$in our control plants $\mathrm{K}^{+}$, $\mathrm{Mg}^{2+}$ and $\mathrm{Ca}^{2+}$ were secreted in similar proportions representing 20, 19 and $27 \%$ of total cations, respectively. Nitrate, phosphate and oxalate secretion was very low or below detection limits, and on average represented less than $1.5 \%$ of the total anions secreted at any salinity treatment (Table 1). This may be due to their rapid incorporation and utilization in the plant metabolism (Ramadan, 2001), and confirms that secretion is a selective phenomenon allowing protection of plant tissues against toxic ions, without losing essential nutrients (Barhoumi et al., 2007).

Chloride/anion ratios were high in the secreted solution compared with leaf sap and remained in both cases relatively constant (Figure 3B). This shows the high selectivity of the secretion mechanism, contributing to maintain the ionic balance and metabolic activity in spite of the high total salt content (Waisel et al., 1986). In contrast to leaf composition, the cation/anion ratio of the secretion was very close to 1 (Figure 3D). Similarly, in other halophytic species the changes of the cation secretion and the variation of the $\mathrm{Cl}^{-}$secretion are highly correlated (Rozema et al., 1981; Sobrado and Greaves, 2000).

\section{CONCLUSIONS}

In conclusion, in A. germinans as in other salt secreting mangrove species, leaf salt glands secrete a variety of ions, but the secretion consists mainly of $\mathrm{NaCl}$. The secretion of both $\mathrm{Na}^{+}$and $\mathrm{Cl}^{-}$was not enough to counteract the increase in the concentrations of these ions in the leaf sap, and succulence did not operate as a mechanism to dilute salt concentration in leaf tissues. Our results contrast with previous reports on several critical points: for example, (i) A. germinans grows well 
without added salt, probably because it uses $\mathrm{K}^{+}$instead of $\mathrm{Na}^{+}$as inorganic osmoticum under this condition, contrarily to what has been reported by others indicating that growth of species of the same genus is inhibited by cultivation without salt additions, and (ii) secretion rates of both $\mathrm{Na}^{+}$and $\mathrm{Cl}^{-}$increased with salinity without showing saturation. Additionally, our results show that $\mathrm{Na}^{+} / \mathrm{K}^{+}$ratios of the secretion increased steadily with the salt treatment, and give a quantitative estimation of the maintenance of $\mathrm{K}^{+}$uptake capacity in spite of large increases in $\mathrm{Na}^{+}$concentration in the nutrient solution. Finally, it is shown for the first time that under high salinity leaf accumulation of $\mathrm{Na}^{+}$is higher than that of $\mathrm{Cl}^{-}$, in correspondence with higher secretion rates of $\mathrm{Cl}^{-}$ compared to $\mathrm{Na}^{+}$, leading to a preferential accumulation of $\mathrm{Na}^{+}$over $\mathrm{Cl}^{-}$in leaf tissues.

Acknowledgements: To CONICIT for providing NS with a PhD fellowship. Financial support for this work was provided by the Instituto Venezolano de Investigaciones Científicas and the International Institute of Tropical Forestry (USDA-Forest Service). To MSc Guillermina Aguiar for assisting with the ion analyses. I am grateful to the editor and anonymous referees for helpful suggestions to improve this manuscript.

\section{REFERENCES}

Albert R, Popp M (1977) Chemical composition of halophytes from the Neusiedler lake region in Austria. Oecologia 27:157-170.

Atkinson MR, Findlay GP, Hope AB, Pitman MG, Saddler HDW, West KR (1967) Salt regulation in the mangrove Rhizophora mucronata Lam. and Aegialitis annulata R. Br. Aust. J. Biol. Sci. 20:589-599.

Ball MC, Cowan IR, Farquhar GD (1988) Maintenance of leaf temperature and the optimization of carbon gain in relation to water loss in a tropical mangrove forest. Aust. J. Plant Physiol. 15:263-270.

Ball MC (1988) Salinity tolerance in the mangroves Aegiceras corniculatum and Avicennia marina. I. Water use in relation to growth, carbon partitioning, and salt balance. Aust. J. Plant Physiol. 15:447-464.

Barhoumi Z, Djebali W, Smaoui A, Chaïbi W, Abdelly C (2007) Contribution of $\mathrm{NaCl}$ excretion to salt resistance of Aeluropus littoralis (Willd) Parl. J. Plant Physiol. 164:842-850.
Boon PI, Allaway WG (1982) Assessment of leaf-washing techniques for measuring salt secretion in Avicennia marina (Forsk.) Vierh. Aust. J. Plant Physiol. 9:725-734.

Boon PI, Allaway WG (1986) Rates and ionic specificity of salt secretion from excised leaves of the mangrove, Avicennia marina (Forsk.) Vierh. Aquat. Bot. 26:143153.

Clough BF (1984) Growth and salt balance of the mangroves Avicennia marina (Forsk.) Vierh. and Rhizophora stylosa Griff. in relation to salinity. Aust. J. Plant Physiol. 11:419-430.

Downton WJS (1982) Growth and osmotic relation of the mangrove Avicennia marina as influenced by salinity. Aust. J. Plant Physiol. 9:519-528.

Drennan P, Pammenter NW (1982) Physiology of salt secretion in the mangrove Avicennia marina (Forsk.) Vierh. New Phytol. 91:1000-1005.

Dschida WJ, Platt-aloia KA, Thomson WW (1992) Epidermal peels of Avicennia germinans (L.) Stearn: a useful system to study the function of salt glands. Ann. Bot. 70:501-509.

Gierth M, Mäser P (2007) Potassium transporters in plants - Involvement in $\mathrm{K}^{+}$acquisition, redistribution and homeostasis. FEBS Lett. 581:2348-2356.

Jennings DH (1976) The effects of sodium chloride on higher plants. Biol. Rev. 51:453-458.

Leshem Y, Levison E (1972) Regulation mechanisms in the salt mangrove Avicennia marina growing on the Sinai littoral. Oecol. Plant. 7:167-176.

Lüttge U (1971) Structure and function of plant glands. Annu. Rev. Plant Physiol. 22: 23-44.

Marcum KB, Anderson SJ, Engelkr MC (1998) Salt gland ion secretion: a salinity tolerance mechanism among five Zoysiagrass species. Crop Sci. 38:806-810.

Marcum KB, Murdoch CL (1992) Salt tolerance of the coastal salt marsh grass, Sporobolus virginicus (L.) Kunth. New Phytol. 120:281-288.

Paliyavuth C, Clough B, Patanaponpaiboon P (2004) Salt uptake and shoot water relations in mangroves. Aquat. Bot. 78:349-360.

Parida AK, Das AB, Mittra B (2004) Effects of salt on growth, ion accumulation, photosynthesis and leaf anatomy of the mangrove, Bruguiera parviflora. Trees 18:167-174.

Pitman MG (1977) Ion transport into the xylem. Annu. Rev. Plant Physiol. 28:71-88. 
Popp M, Larcher F, Weigel P (1985) Osmotic adaption in Australian mangroves. Vegetatio 61:247-253.

Rada F, Goldstein G, Orozco A, Montilla M, Zabala M, Azócar A (1989) Osmotic and turgor relations of three mangrove ecosystem species. Aust. J. Plant Physiol. 16:722-729.

Rain DW, Epstein E (1967) Preferential absorption of potassium by leaf tissue of the mangrove, Avicennia marina: and aspect of halophytic competence in coping with salt. Aust. J. Biol. Sci. 20:847-857.

Ramadan T (2001) Dynamics of salt secretion by Sporobolus spicatus (Vahl) Kunth from sites of differing salinity. Ann. Bot. 87:259-266.

Rozema J, Gude H, Pollak G (1981) An ecophysiological study of the salt secretion of four halophytes. New Phytol. 89:201-217.

Rozema J, Riphagen I (1977) Physiological and ecological relevance of salt secretion by salt glands of Glaux maritina L. Oecologia 29:329-357.

Scholander PF, Hammel HT, Hemmimgsen EA, Garey W (1962) Salt balance in mangrove. Plant Physiol. 37:722729.

Sobrado MA (2001) Effect of high external $\mathrm{NaCl}$ concentration on the osmolality of xylem sap, leaf tissue and leaf glands secretion of the mangrove
Avicennia germinans (L.) L. Flora 196:63-70.

Sobrado MA, Greaves ED (2000) Leaf secretion composition of the mangrove species Avicennia germinans (L.) in relation to salinity: a case study by using total-reflection X-ray fluorescence analysis. Plant Sci. 159:1-5.

Sokal RR, Rohlf FJ (1969) Biometry. W. H. Freeman and Company, San Francisco.

Suárez N, Medina E (2005) Salinity effect on plant growth and leaf demography of the mangrove, Avicennia germinans L. Trees 19:721-727.

Suárez N, Medina E (2006) Influence of salinity on $\mathrm{Na}^{+}$ and $\mathrm{K}^{+}$accumulation, and gas exchange in Avicennia germinans. Photosynthetica 44:268-274.

Suárez N, Sobrado MA (2000) Adjustments in leaf water relations of mangrove (Avicennia germinans) seedlings grown in a salinity gradient. Tree Physiol. 20:277-282.

Tomlinson PB (1986) The Botany of Mangroves. Cambridge University Press, London.

Waisel Y (1972) Biology of Halophytes. Academic Press, New York.

Waisel Y, Eshel A, Agami M (1986) Salt balance of leaves of the mangrove Avicennia marina. Physiol. Plant. 67:67-72. 